OAK RIDGE

NATIONAL LABORATORY

MANAGED BY UT-BATTELLE

FOR THE DEPARTMENT OF ENERGY

\title{
Probabilistic Mechanical Reliability Prediction of Thermoelectric Legs
}

Osama M. Jadaan

College of Engineering, Mathematics, and Science

University of Wisconsin-Platteville

Platteville, WI 53818

jadaan@uwplatt.edu

Andrew A. Wereszczak

Ceramic Science and Technology Group Materials Science and Technology Division

Oak Ridge National Laboratory

Oak Ridge, TN 37831-6068

wereszczakaa@ornl.gov

Publication Date: May 2009

Prepared by the

OAK RIDGE NATIONAL LABORATORY

Oak Ridge, Tennessee 37831

managed by

UT-BATTELLE, LLC

for the

U.S. DEPARTMENT OF ENERGY

Under contract DE-AC05-00OR22725

\section{UT-BATTELLE}




\section{DOCUMENT AVAILABILITY}

Reports produced after January 1, 1996, are generally available free via the U.S. Department of Energy (DOE) Information Bridge:

Web site: http://www.osti.gov/bridge

Reports produced before January 1, 1996, may be purchased by members of the public from the following source:

National Technical Information Service

5285 Port Royal Road

Springfield, VA 22161

Telephone: 703-605-6000 (1-800-553-6847)

TDD: $703-487-4639$

Fax: 703-605-6900

E-mail: info@ntis.fedworld.gov

Web site: http://www.ntis.gov/support/ordernowabout.htm

Reports are available to DOE employees, DOE contractors, Energy Technology Data Exchange (ETDE) representatives, and International Nuclear Information System (INIS) representatives from the following source:

Office of Scientific and Technical Information

P.O. Box 62

Oak Ridge, TN 37831

Telephone: $865-576-8401$

Fax: 865-576-5728

E-mail: reports@osti.gov

Web site: http://www.osti.gov/contact.html

This report was prepared as an account of work sponsored by an agency of the United States Government. Neither the United States government nor any agency thereof, nor any of their employees, makes any warranty, express or implied, or assumes any legal liability or responsibility for the accuracy, completeness, or usefulness of any information, apparatus, product, or process disclosed, or represents that its use would not infringe privately owned rights. Reference herein to any specific commercial product, process, or service by trade name, trademark, manufacturer, or otherwise, does not necessarily constitute or imply its endorsement, recommendation, or favoring by the United States Government or any agency thereof. The views and opinions of authors expressed herein do not necessarily state or reflect those of the United States Government or any agency thereof. 


\section{TABLE OF CONTENTS}

Page

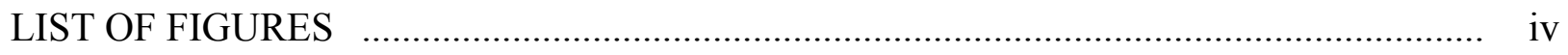

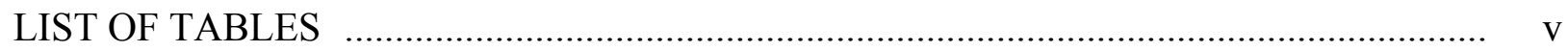

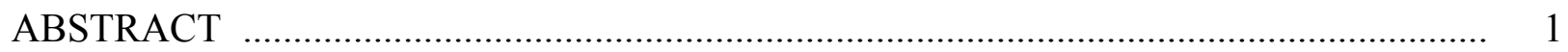

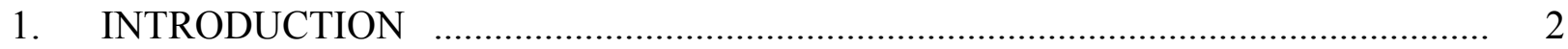

2. FINITE ELEMENT ANALYSIS MODELING _......................................................... 3

3. FINITE ELEMENT ANALYSIS RESULTS ………........................................ 14

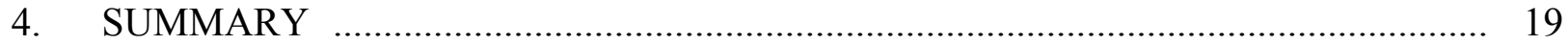

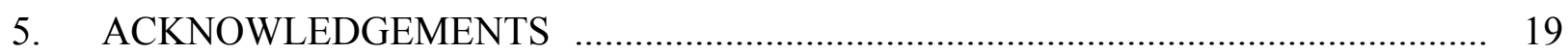

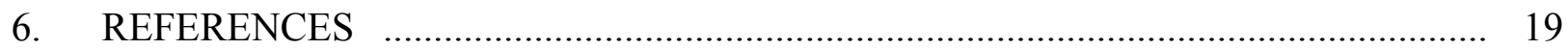




\section{LIST OF FIGURES}

Figure

Page

1. Various views of the base design for the $8 \times 8$ TED with: purple being the alumina insulator plates, turquoise being the solder contacts and mounting layer, and red being the TEMat legs.

2. Various views of the $8 \times 8$ TED with the insulator plates removed here to display the geometric arrangement of the TEMat legs and the solder contacts.

3. Various views of the reference $8 \times 8$ TED square leg array.

4. The three array configurations investigated in this work. $6 \times 6$ (top), $8 \times 8$ (middle), and $10 \times 10$ (bottom). All legs have the same dimensions though the above figures visually indicate otherwise.

5. Various views of the typical mesh distribution.

6. Various views of the temperature distribution in the $8 \times 8 \mathrm{Bi}_{2} \mathrm{Te}_{3}$ TED cooler.

7. Various views of the temperature distribution in the $8 \times 8 \mathrm{PbTe}$ and skutterudite TED heaters.

8. Various views of the temperature gradient distribution in $\mathrm{a}_{2} \mathrm{Te}_{3} 8 \times 8$ TED cooler. 11

9. Deformed 8 x 8 TED supported using $\mathrm{BC} 1$ with deformations magnified 30x. ....... 12

10. Deformed TED supported using BC2 with deformations magnified 30x. .............. 12

11. $\mathrm{Bi}_{2} \mathrm{Te}_{3}$ TED with solder mounting plate placed against the bottom or cold-side alumina plate.

12. $\mathrm{PbTe}$ and skutterudite TED with solder mounting plate placed against the top or hot-side alumina plate. 


\section{LIST OF TABLES}

\section{Table}

\section{Page}

I. Thermomechanical and Weibull material properties. Shown Weibull parameters pertain to volume-type-flaw strength-limiting.

II. Dimensions of TE device.

III. Bismuth telluride $\left(\mathrm{Bi}_{2} \mathrm{Te}_{3}\right)$ with $\Delta \mathrm{T}=100^{\circ} \mathrm{C}$, temperature at hot-side surface $=150^{\circ} \mathrm{C}$, and temperature at cold-side surface $=50^{\circ} \mathrm{C}$.

IV. Lead telluride ( $\mathrm{PbTe}$ ) with $\Delta \mathrm{T}=250^{\circ} \mathrm{C}$, temperature at hot-side surface $=450^{\circ} \mathrm{C}$, and temperature at cold-side surface $=200^{\circ} \mathrm{C}$.

V. Skutterudite with $\Delta \mathrm{T}=250^{\circ} \mathrm{C}$, temperature at hot-side surface $=450^{\circ} \mathrm{C}$, and temperature at cold-side surface $=200^{\circ} \mathrm{C}$. 


\begin{abstract}
The probability of failure, $\mathrm{P}_{\mathrm{f}}$, for various square-arrayed thermoelectric device designs using bismuth telluride, lead telluride, or skutterudite thermoelectric materials were estimated. Only volume- or bulk-based $\mathrm{P}_{\mathrm{f}}$ analysis was considered in this study. The effects of the choice of the thermoelectric material, the size of the leg array, the height of the thermoelectric legs, and the boundary conditions on the $\mathrm{P}_{\mathrm{f}}$ of thermoelectric devices were investigated. Yielding of the solder contacts and mounting layer was taken into account. The modeling results showed that the use of longer legs, using skutterudites, allowing the thermoelectric device to freely deform while under a thermal gradient, and using smaller arrays promoted higher probabilities of survival.
\end{abstract}




\section{INTRODUCTION}

The research of thermoelectric materials (TEMats) for power generation from waste heat and for solid state heating and cooling applications is very active. The thermoelectric function and efficiency of these materials (and consequently, the thermoelectric devices, TEDs, that comprise them) are dependent on the Seebeck coefficient, the electrical resistivity, and the thermal conductivity. For a maximum figure of merit, the Seebeck coefficient needs to be maximized and both the electrical resistivity and thermal conductivity need to be minimized.

However, an efficient TEMat can only be exploited if it is able to withstand imposed thermal gradients and thermal transients of service. A thermal gradient is what activates the thermoelectric effect, so the associated thermomechanical stresses (particulartly, the tensile stresses) must be managed to achieve reliability. Therefore, the engineering to minimize the imposed thermomechanical stresses must be incorporated into a TED for a selected TEMat.

Kingery's [1] thermal resistance parameter, $\mathrm{R}_{\text {Therm, }}$, is useful to refer to in context with TEMats,

$$
R_{\text {Therm }}=\frac{S_{\text {Tens }}(1-v) \kappa}{\alpha E}
$$

where $\mathrm{S}_{\text {Tens }}$ is tensile stress or tensile strength, $v$ is Poisson's ratio, $\kappa$ is thermal conductivity, $\alpha$ is the coefficient of thermal expansion or CTE, and $\mathrm{E}$ is elastic modulus. For improved thermomechanical resistance against effects caused by thermal gradients or thermal transients, one desires $\mathrm{R}_{\text {Therm }}$ to be as large as possible. The parameters $v, \kappa, \alpha$, and $\mathrm{E}$ are materials properties and are essentially unchangeable for any given TEMat under consideration. As mentioned above, the minimization of $\kappa$ for a TEMat is purposely sought because that achievement improves thermoelectric efficiency. Additionally, almost all TEMats [2-4] typically have a large CTE $\left(>10 \mathrm{ppm} /{ }^{\circ} \mathrm{C}\right)$. Therefore, the intent to make the $\mathrm{R}_{\text {Therm }}$ for TEMats as large as possible is primarily hindered by the inherently low $\kappa$ and typically high CTE. The $v$ for most TEMats is on the order of 0.20-0.25. The E's for TEMats (e.g., tellurides, skutterudites, TAGS, etc.) typically range between 50-125 GPa.

The remaining parameter in Eq. 1 is therefore (tensile) strength. The $\mathrm{S}_{\text {Tens }}$ for brittle materials, including TEMats, is not a single value. The $\mathrm{S}_{\text {Tens }}$ for brittle materials is a function of many parameters (e.g., size) that are either intrinsic or extrinsic to the material. Because of TEMat brittleness (i.e., low fracture toughness), the $\mathrm{S}_{\text {Tens }}$ is anticipated to be at least one order of magnitude lower than compressive strength in TEMats as is the case for polycrystalline ceramics; therefore, for conservative design, testing will and should focus on the measurement of a tensile strength in TEMats. Of all the parameters used in the right-hand side of Eq. 1, the manufacturer of TEMats and TEDs can only tangibly increase $\mathrm{R}_{\text {Therm }}$ by increasing $\mathrm{S}_{\text {Tens. }}$. But any increase in $\mathrm{S}_{\text {Tens }}$ should be considered in context with brittle-material or Weibull strengthsize-scaling; that is where probabilistic analysis needs to be introduced, and what therefore becomes a primary motivation of the analysis that follows. 
The probability of failure $\left(\mathrm{P}_{\mathrm{f}}\right)$ for various square-arrayed TED designs using three different commercially available TEMats were computed to determine an optimum geometric-material system. Only volume- or bulk-based Pf analysis was considered in this study for the sake of demonstrating the analysis method; the authors recognize though that surface- and edge-based analysis should also be considered for any thorough TED design endeavor. The effects of the following parameters on the $\mathrm{P}_{\mathrm{f}}$ of TEDs were investigated:

1. choice of the TEMat,

2. size of the TE-leg square array of a TED,

3. height of TE legs, and

4. boundary condition.

Yielding of the solder contacts and mounting layer was taken into account.

\section{FINITE ELEMENT ANALYSIS MODELING}

Three different TEMats were considered in the finite element analysis (FEA):

1. bismuth telluride $\left(\mathrm{Bi}_{2} \mathrm{Te}_{3}\right)$,

2. lead telluride $(\mathrm{PbTe})$, and

3. skutterudite.

The mechanical, thermal, and Weibull parameters for these materials are listed in Table I. Any variations of those properties between $\mathrm{n}$ - and p-type derivatives for any of those three materials were not considered. Though some of these materials may have material anisotropy [2], the proceeding analysis assumed that they are isotropic and homogeneous.

The geometry of the (base or reference) $8 \times 8$ leg array TED with colors corresponding to the material sequence is shown in Fig. 1. In this schematic, purple corresponds to the alumina ceramic insulator plates, turquoise to the solder contacts and mounting plate, and red is the TE legs. Various views of the TED are shown in Fig. 2 with the insulator plates removed here to clearly display the geometric arrangement of the solder contacts. The $8 \times 8$ TED is shown in Fig. 3. The general dimensions of the various components comprising the $8 \times 8$ TED are listed in Table II.

Three different square TED leg array sizes were investigated. They were:

1. $6 \times 6$ array,

2. $8 \times 8$ array (base- or reference-model), and

3. $10 \times 10$ array.

These three TE array designs are shown in Fig. 4 and were analyzed to study the size effect on the $\mathrm{P}_{\mathrm{f}}$. A typical FEA mesh distribution is shown in Fig. 5. 
Table I. Thermomechanical and Weibull material properties. Shown Weibull parameters pertain to volume-type-flaw strength-limiting.

\begin{tabular}{|c|c|c|c|c|c|}
\hline Property & $\begin{array}{l}\text { Bismuth } \\
\text { Telluride }\end{array}$ & $\begin{array}{c}\text { Lead } \\
\text { Telluride } \\
\end{array}$ & Skutterudite & $\begin{array}{c}\text { Alumina } \\
\text { Substrate }\end{array}$ & Solder \\
\hline $\begin{array}{c}\mathrm{E} \\
(\mathrm{GPa})\end{array}$ & 45 & 50 & 110 & 360 & 12.5 \\
\hline $\begin{array}{c}\text { Poisson's } \\
\text { Ratio } \\
\end{array}$ & 0.22 & 0.22 & 0.21 & 0.24 & 0.36 \\
\hline $\begin{array}{c}\kappa \\
(\mathrm{W} / \mathrm{m} \cdot \mathrm{K})\end{array}$ & 1.4 & 2.8 & 3 & 25 & 15 \\
\hline $\begin{array}{c}\mathrm{CTE} \\
\left(\mathrm{ppm} /{ }^{\circ} \mathrm{C}\right)\end{array}$ & 18 & 20 & 10 & 8 & 26 \\
\hline $\begin{array}{l}\text { Weibull } \\
\text { Modulus }\end{array}$ & 5 & 5 & 5 & 15 & \\
\hline 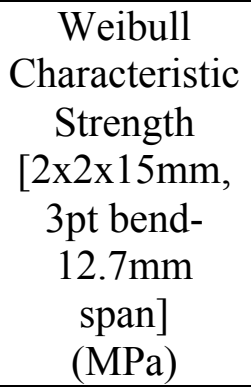 & 60 & 50 & 100 & & \\
\hline $\begin{array}{c}\text { Volume } \\
\text { Scale } \\
\text { Parameter } \\
\left(\mathrm{MPa} \cdot \mathrm{mm}^{3 / \mathrm{m}}\right)\end{array}$ & 56.0 & 40.6 & 89.3 & 500 & \\
\hline $\begin{array}{c}\text { Yield } \\
\text { Strength } \\
(\mathrm{MPa})\end{array}$ & & & & & 22 \\
\hline
\end{tabular}

Table II. Dimensions of TE device.

\begin{tabular}{|c|c|}
\hline Dimension & Magnitude (mm) \\
\hline Alumina insulator plate width & 50 \\
\hline Top alumina insulator plate length & 57 \\
\hline Bottom alumina insulator plate length & 50 \\
\hline Alumina insulator plate thickness & 2 \\
\hline Mounting solder plate thickness & 0.5 \\
\hline TE leg width & 4 \\
\hline TE leg heights & 3 and 6 \\
\hline Contact thickness & 1.5 \\
\hline Spacing between contacts & 2 \\
\hline
\end{tabular}




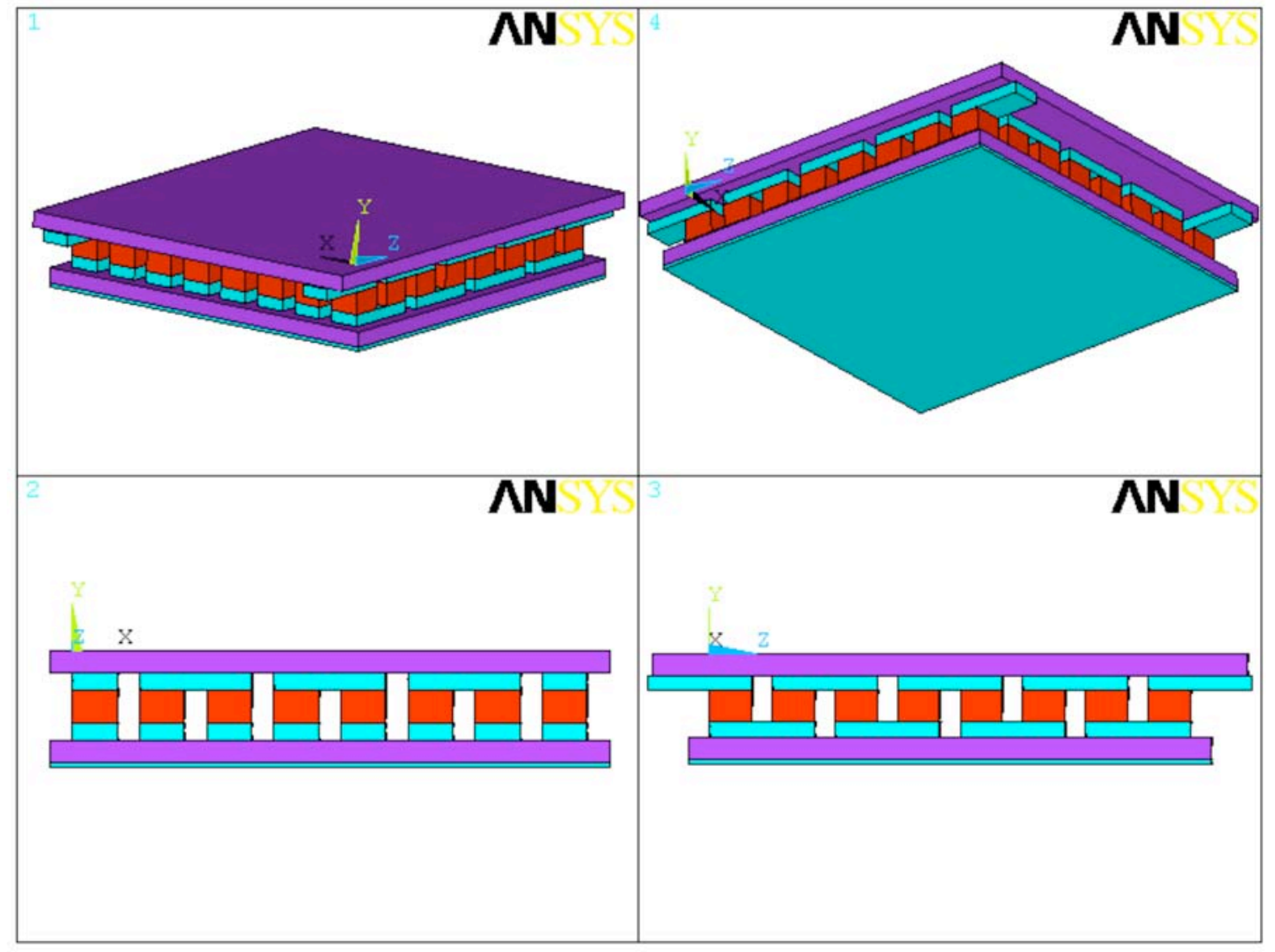

Figure 1. Various views of the base design for the $8 \times 8$ TED with: purple being the alumina insulator plates, turquoise being the solder contacts and mounting layer, and red being the TEMat legs. 


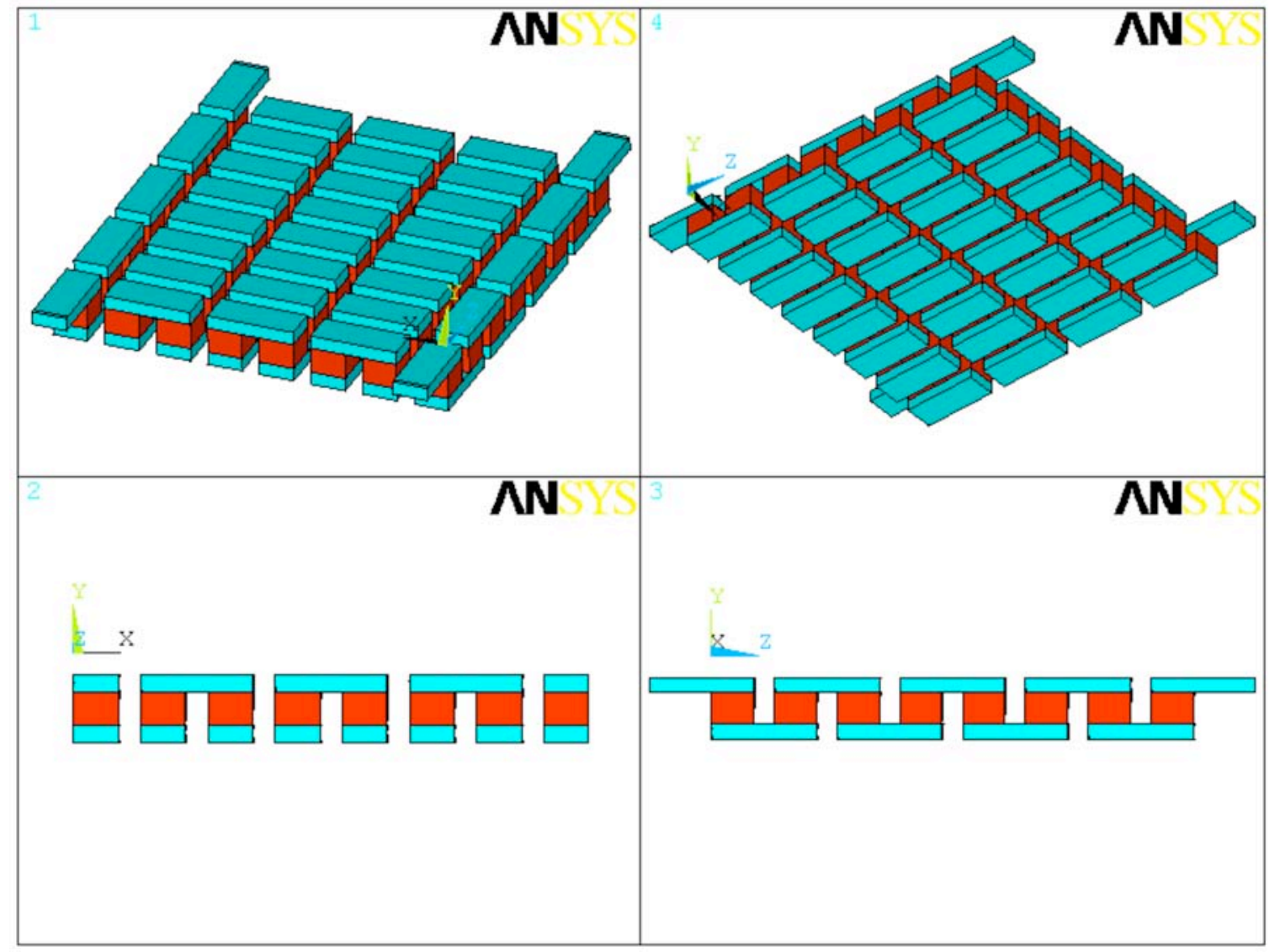

Figure 2. Various views of the $8 \times 8$ TED with the insulator plates removed here to display the geometric arrangement of the TEMat legs and the solder contacts. 


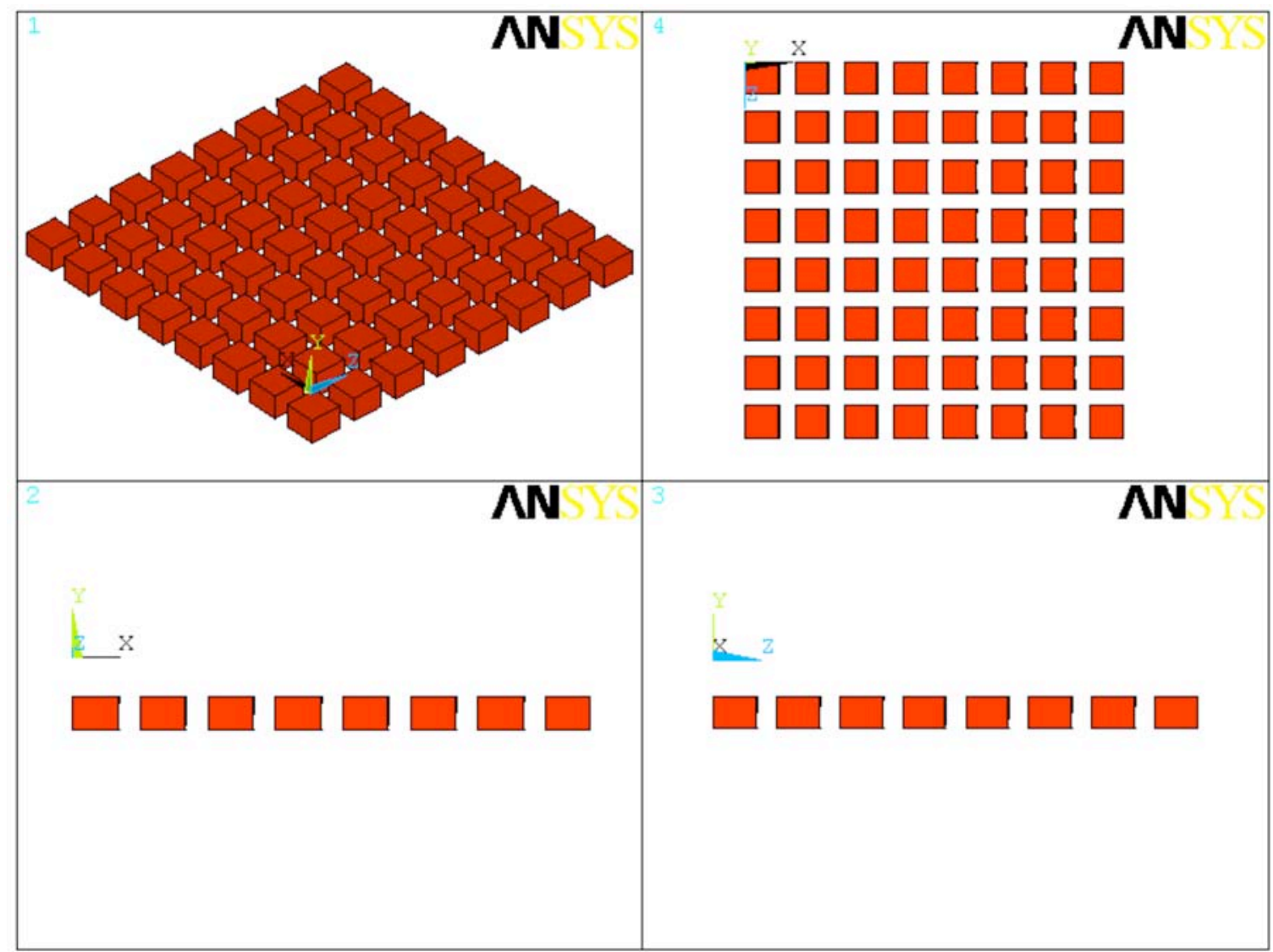

Figure 3. Various views of the reference $8 \times 8$ TED square leg array. 

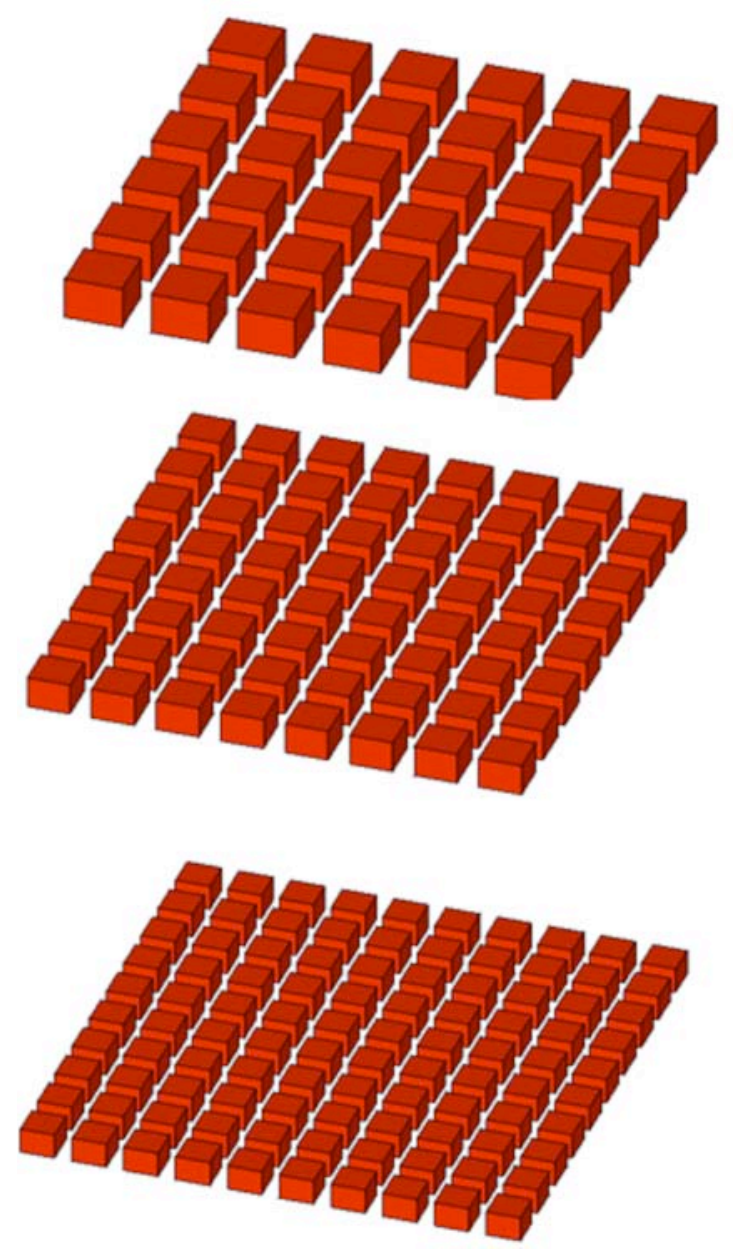

Figure 4. The three array configurations investigated in this work. $6 \times 6$ (top), $8 \times 8$ (middle), and $10 \times 10$ (bottom). All legs have the same dimensions though the above figures visually indicate otherwise. 


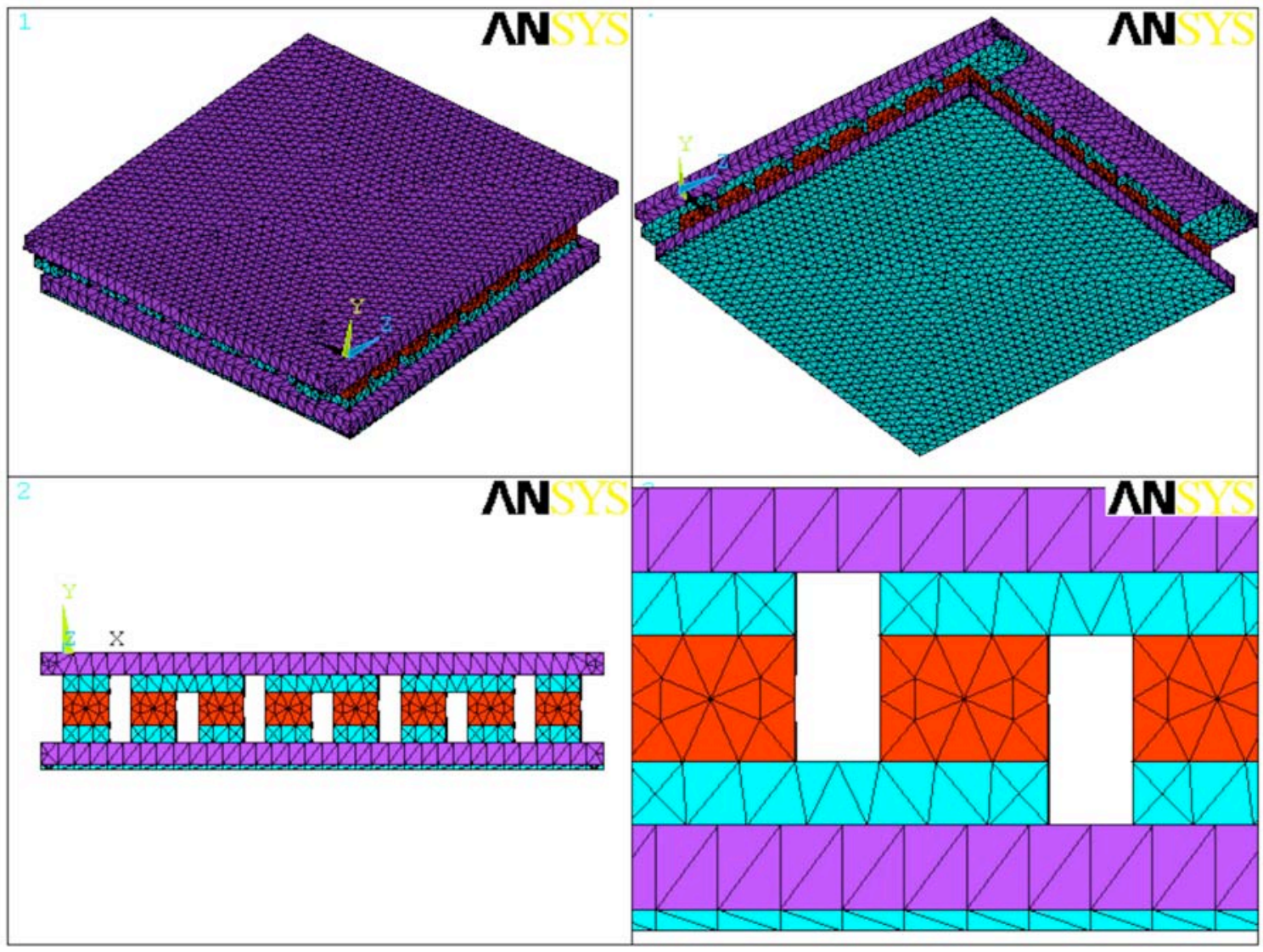

Figure 5. Various views of the typical mesh distribution.

The temperature distribution throughout the $\mathrm{Bi}_{2} \mathrm{Te}_{3} 8 \times 8$ TED is shown in Fig. 6. Only steadystate thermal analysis was considered in this study. In the example shown in Fig. 6, the temperatures were set to $150^{\circ} \mathrm{C}$ at the top surface of the hot alumina plate and $50^{\circ} \mathrm{C}$ at the bottom surface of the mounting solder layer. A strain-free temperature of $200^{\circ} \mathrm{C}$ was assumed.

The temperature distributions throughout the PbTe and skutterudite TEDs are shown in Fig. 7. In these steady state thermal analyses, the temperatures were set to $450^{\circ} \mathrm{C}$ at the top surface of the hot mounting solder layer and $200^{\circ} \mathrm{C}$ at the bottom surface of the cold alumina plate. A strain free temperature of $500^{\circ} \mathrm{C}$ was assumed.

The temperature gradient distribution in $\mathrm{a}_{2} \mathrm{Te}_{3} 8 \times 8 \mathrm{TE}$ cooler is shown in Fig. 8. Note with a $\mathrm{TE}$ leg height of $3 \mathrm{~mm}$ and $\Delta \mathrm{T}=100^{\circ} \mathrm{C}$, that the temperature gradient is approximately $33^{\circ} \mathrm{C} / \mathrm{mm}$ in the TE leg (which has significantly lower thermal conductivity than that for the substrate and contact materials). 


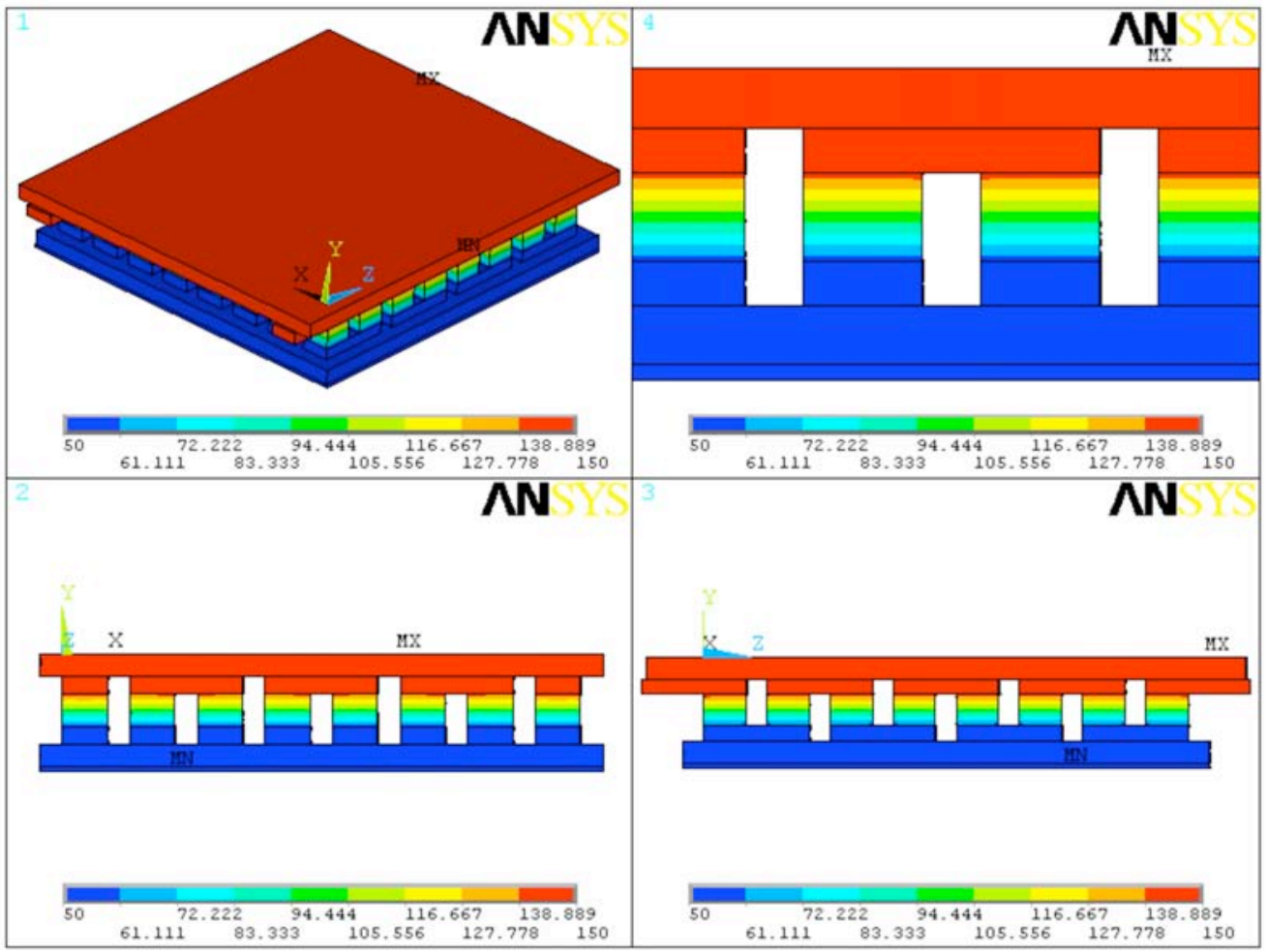

Figure 6. Various views of the temperature distribution in the $8 \times 8 \mathrm{Bi}_{2} \mathrm{Te}_{3}$ TED cooler.
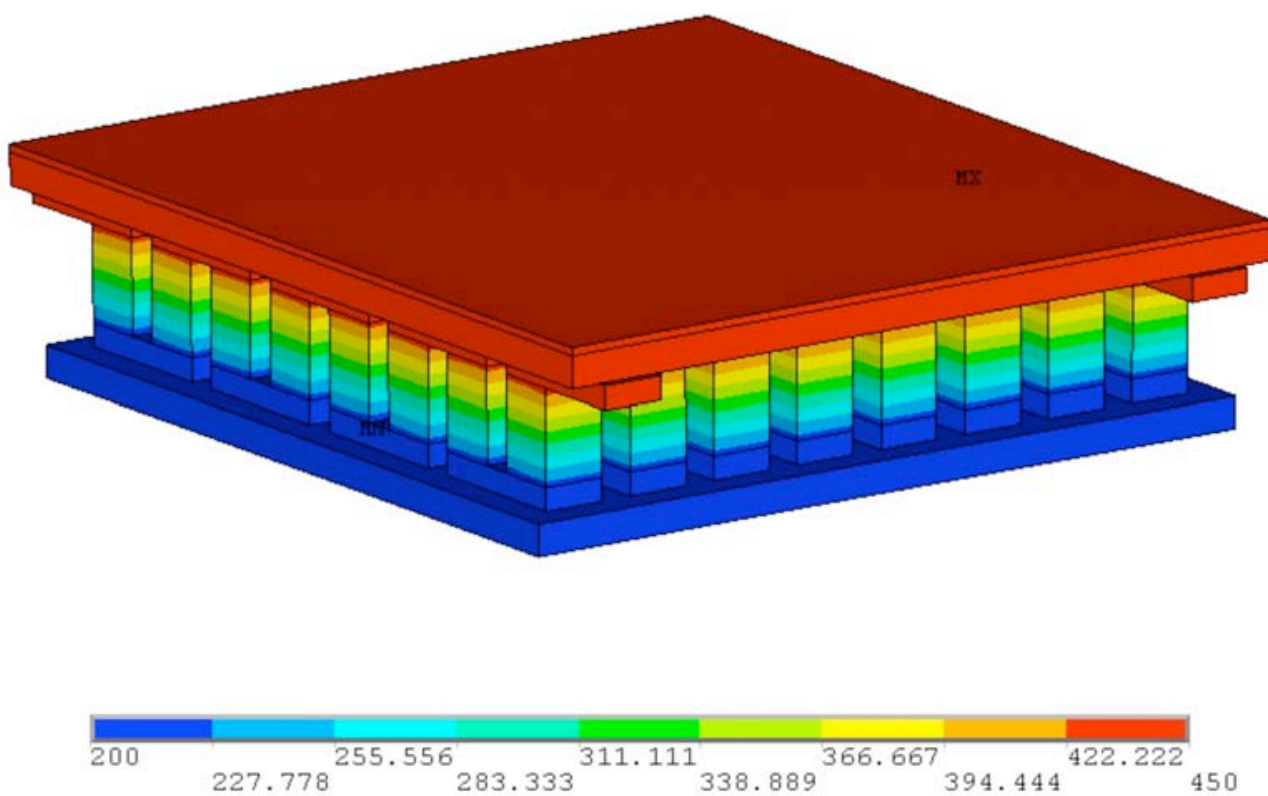

Figure 7. Various views of the temperature distribution in the $8 \times 8 \mathrm{PbTe}$ and skutterudite TED heaters. 


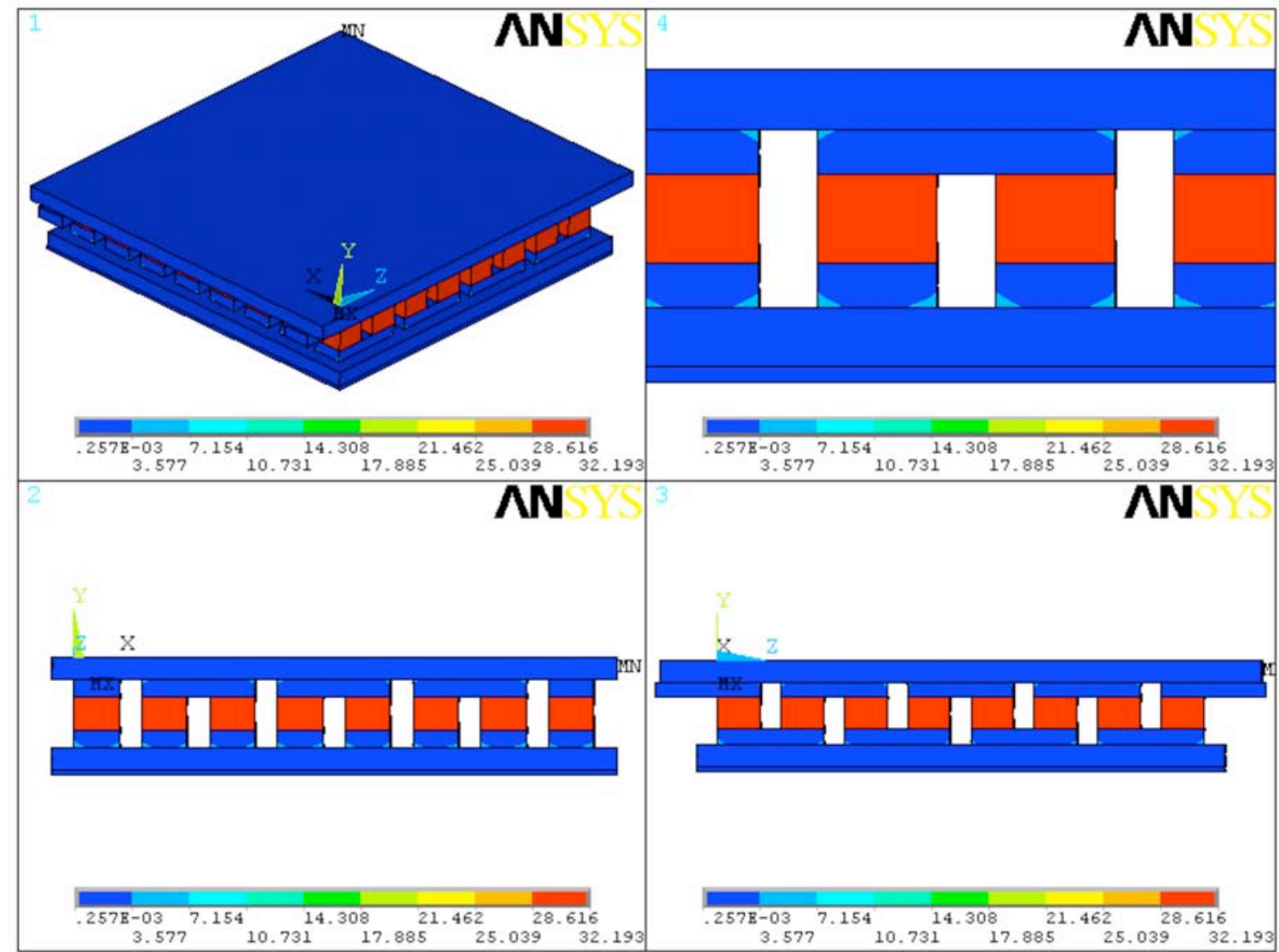

Figure 8. Various views of the temperature gradient distribution in $\mathrm{Bi}_{2} \mathrm{Te}_{3} 8 \times 8$ TED cooler.

The effect of boundary condition (BC) on the stress state and $\mathrm{P}_{\mathrm{f}}$ for the various TE device designs was also investigated. The method of supporting a TE device, which depending on the $\mathrm{BC}$, could restrict free displacement due to thermal loading resulting in high stresses and $\mathrm{P}_{\mathrm{f}}$. To examine this, the following two structural boundary conditions (BC1 and $\mathrm{BC} 2)$ were considered:

1. BC1 (Fig. 9). TED suspended at a single node at the top surface. This represents a stress-relieving method of mounting a TED that would permit free displacement. This case represents a lower bound for stress and $\mathrm{P}_{\mathrm{f}}$.

2. BC2 (Fig. 10). TED mounted against a flat surface using rollers. This method of structurally mounting the TED would sustain flatness and prevent curling caused by the applied thermal load and coefficient of thermal explansion. However, this in turn would impose added stresses to those generated via the applied thermal gradient. This case represents an upper bound for stress and $\mathrm{P}_{\mathrm{f}}$. 


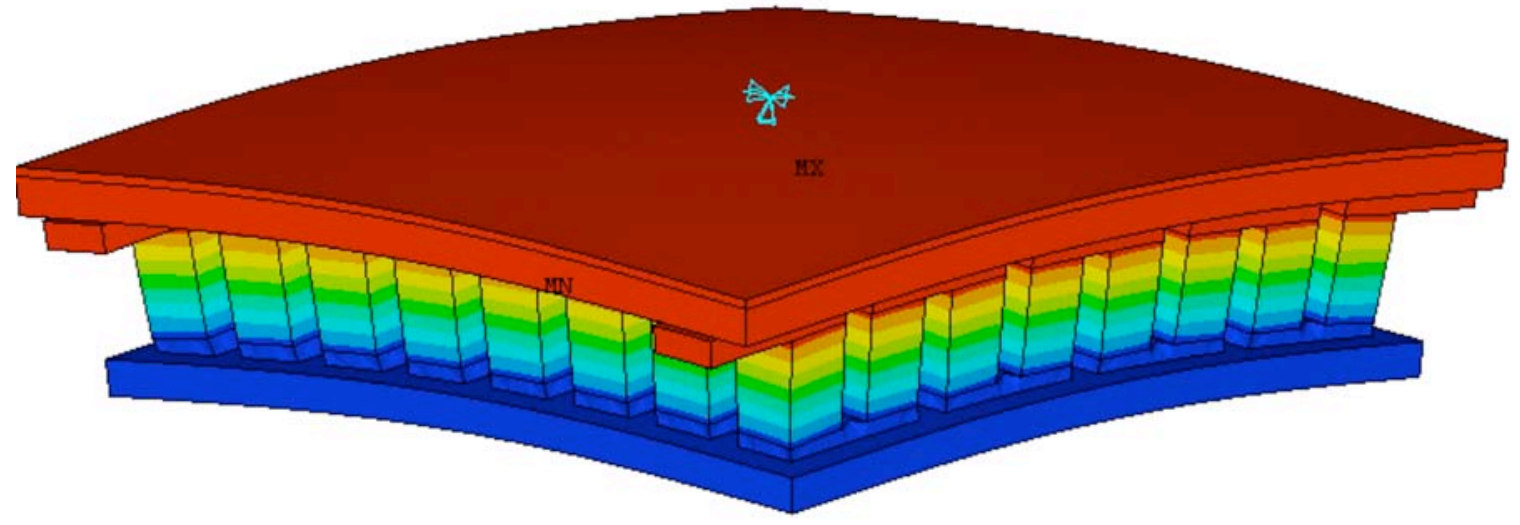

Figure 9. Deformed 8 × 8 TED supported using $\mathrm{BC} 1$ with deformations magnified 30x.

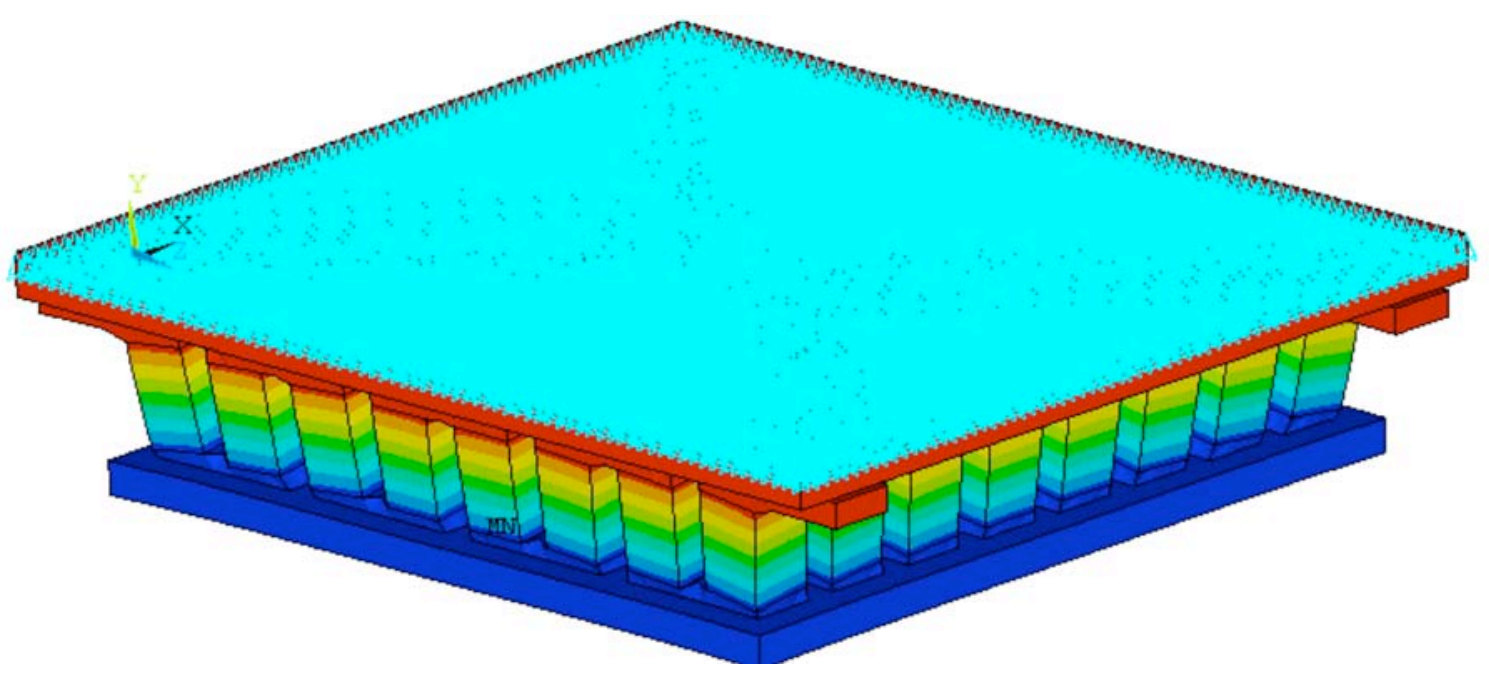

Figure 10. Deformed TED supported using BC2 with deformations magnified $30 \mathrm{x}$.

In all FEA models, a solder plate was used to mount the TEDs to the boundary conditions. Namely, this solder mounting layer was placed against the cold-side for the Bi2Te3 TED (bottom surface in Fig. 11) and against the hot-side of the PbTe and skutterudite TEDs (top surface in Fig. 12). 


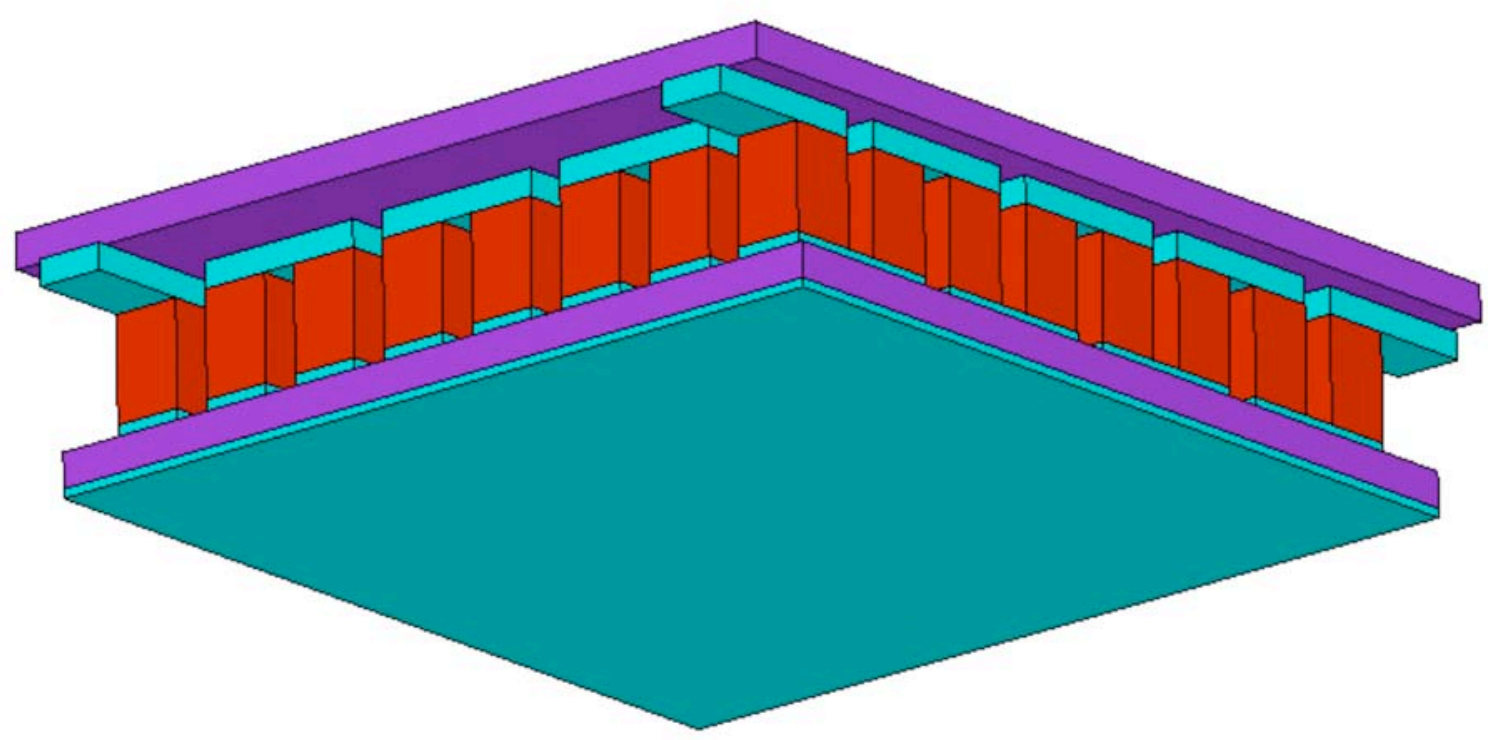

Figure 11. $\mathrm{Bi}_{2} \mathrm{Te}_{3} \mathrm{TED}$ with solder mounting plate placed against the bottom or cold-side alumina plate.

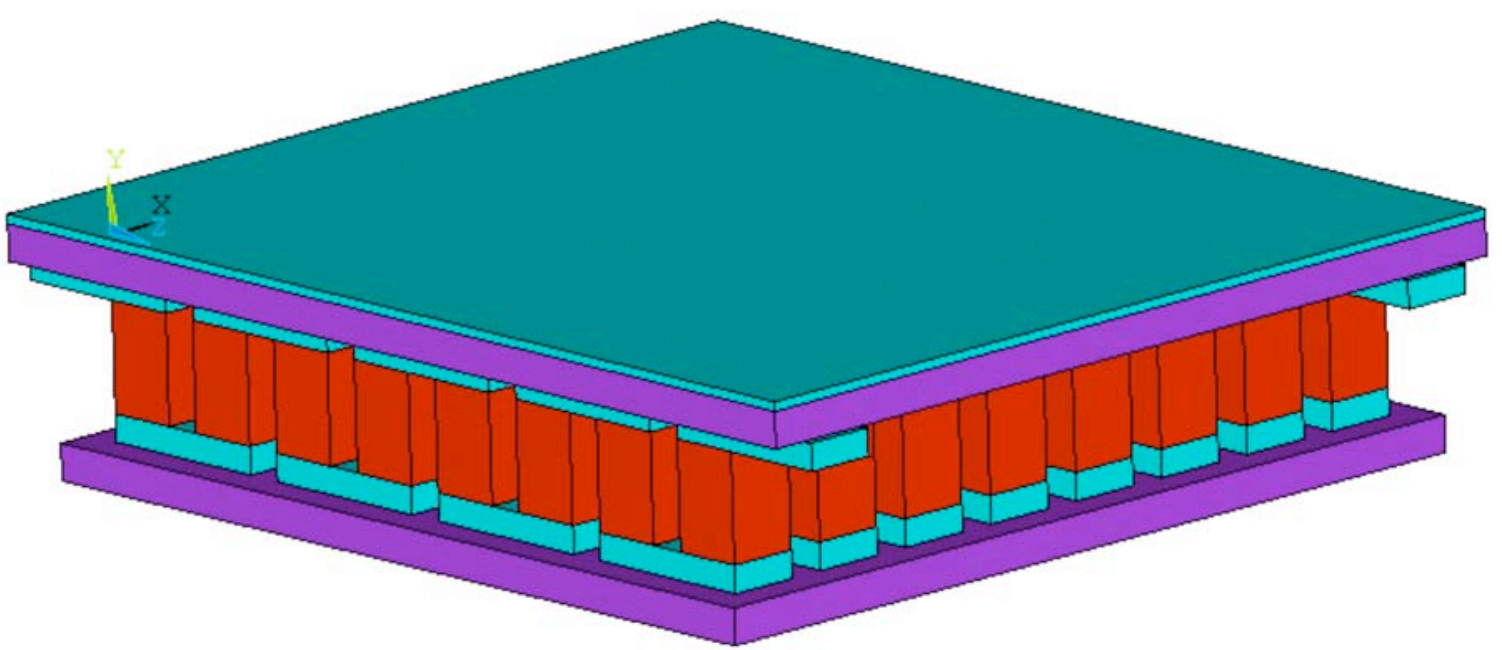

Figure 12. PbTe and skutterudite TED with solder mounting plate placed against the top or hot-side alumina plate. 


\section{FINITE ELEMENT ANALYSIS RESULTS}

The stress and probability of failure results for all systems considered are summarized in Tables III-V. In theses analyses, elastic-plastic behavior in the solder material was taken into account (yield strength $=22 \mathrm{MPa}$ per Table I).

The CARES software (Ceramics Analysis and Reliability Evaluation of Structures, Connecticut Reserve Technologies, Gates Mills, $\mathrm{OH}$ ) code was used to compute the $\mathrm{P}_{\mathrm{f}}$ for the brittle material constituents (i.e., thermoelectric legs and the alumina substrates) of the TEDs.

The following is a summary of the results shown in Tables III-V. As with any FEA, the following results and associated observations pertain to the combination of the employed FEA geometries, meshing, boundary conditions, and materials properties; if any of those are inaccurate or unrealistic, then the reader is cautioned that the following observations could or will be different. Additionally, this study's analysis pertained only to volume-based probabilistic analysis; concurrent surface- and edge-based analysis should also be performed for any thorough and conclusive design efforts.

- Longer TE legs are more reliable since they result in reduced stresses compared to shorter legs, especially for $\mathrm{BC} 1$. For example, by doubling the height of the $\mathrm{Bi}_{2} \mathrm{Te}_{3}$ legs from 3 to $6 \mathrm{~mm}$ in the $8 \times 8 \mathrm{TED}$, and using $\mathrm{BC}$, the maximum first principal tensile stress (S1) decreased by about $20 \%$ from $48.7 \mathrm{MPa}$ to $39.1 \mathrm{MPa}$.

- The $\mathrm{S} 1$ is higher in the $\mathrm{PbTe}$ and shutterudite TED compared to that in the $\mathrm{Bi}_{2} \mathrm{Te}_{3} \mathrm{TED}$ because their thermal loadings and material stiffnesses are higher.

- The $\mathrm{P}_{\mathrm{f}}$ is almost entirely due to fracture in the TE legs. The $\mathrm{P}_{\mathrm{f}}$ in the alumina substrate plates is essentially zero. This is due to the low strength and the low Weibull moduli of the TEMats compared to those for alumina.

- The PbTe TED will fail because the probability of failure reaches $100 \%$. This is due to the high thermal stress and low strength. The temperature gradient in this module is $250^{\circ} \mathrm{C}$ compared to $100^{\circ} \mathrm{C}$ for the $\mathrm{Bi}_{2} \mathrm{Te}_{3}$ device. In addition, $\mathrm{PbTe}$ is weaker than $\mathrm{Bi}_{2} \mathrm{Te}_{3}$.

- Even though the maximum S1 stress in the skutterudite TED is higher than that in the PbTe TED, they are still more reliable (even though both are subjected to the same temperature gradient). This is simply because skutterudite is stronger than PbTe. However, the majority of the skutterudite TEDs would still fail under the considered thermal loading.

- For the skutterudite TEDs, the S1 stress in the legs decreases as the height of the legs increases, as stated above. However, the decrease in S1 stress is not significant enough to offset the increase in volume of material leading to slightly higher $\mathrm{P}_{\mathrm{f}}$ for the skutterudite TEDs with longer legs. The opposite behavior is predicted for the $\mathrm{Bi}_{2} \mathrm{Te}_{3} \mathrm{TEDs}$, since the drop in stress for taller legs is more significant. 
- BC2 (with cold-side surface for the $\mathrm{Bi}_{2} \mathrm{Te}_{3}$ TEDs and hot-side surface for the PbTe and skutterudite TEDs restrained with rollers representing vertical bonding to a surface) is more detrimental than $\mathrm{BC} 1$. This is because in $\mathrm{BC}$, the stress in the TE legs increases while the stress in the insulator plates does not change much, relative to $\mathrm{BC} 1$. With the TEMats being weaker than the alumina, $\mathrm{BC} 2$ superimposed more stresses into the TEDs.

- For BC2, 100\% of all TEDs are predicted to fail.

- Using a smaller TED with a $6 \times 6$ array reduces the maximum S1 stress in the alumina plates but keeps the maximum stress essentially the same in the legs. This will lead to improved reliability because of the smaller total volume for the TE legs. For example, the $\mathrm{P}_{\mathrm{f}}=0.463$ for the $8 \times 8 \mathrm{Bi}_{2} \mathrm{Te}_{3}$ TED with $\mathrm{BC} 1$, while $\mathrm{P}_{\mathrm{f}}=0.335$ for the $6 \times 6$ TED. 
Table III. Bismuth telluride $\left(\mathrm{Bi}_{2} \mathrm{Te}_{3}\right)$ with $\Delta \mathrm{T}=100^{\circ} \mathrm{C}$, temperature at hot-side surface $=150^{\circ} \mathrm{C}$, and temperature at cold-side surface $=50^{\circ} \mathrm{C}$.

\begin{tabular}{|c|c|c|c|c|c|}
\hline $\begin{array}{l}\text { Array } \\
\text { size }\end{array}$ & $\begin{array}{l}\text { TE leg } \\
\text { height }\end{array}$ & $\begin{array}{l}\text { Boundary } \\
\text { conditions }\end{array}$ & component & $\begin{array}{c}\text { Max S1 } \\
(\mathrm{MPa})\end{array}$ & Probability of failure \\
\hline \multirow[t]{12}{*}{$6 \times 6$} & \multirow[t]{6}{*}{3} & \multirow[t]{3}{*}{$1^{*}$} & TE legs & 49.7 & \multirow{3}{*}{$\begin{aligned} \mathrm{P}_{\mathrm{fv}, \mathrm{TE}} & =0.335 \\
\mathrm{P}_{\mathrm{fv}, \text { insulator }} & =0.33 \mathrm{e}-13 \\
\mathrm{P}_{\mathrm{fv}, \text { total }} & =0.335\end{aligned}$} \\
\hline & & & Insulator plates & 54.9 & \\
\hline & & & Solder contacts & 27.0 & \\
\hline & & \multirow[t]{3}{*}{$2^{\#}$} & TE legs & 60.3 & \multirow{3}{*}{$\begin{aligned} \mathrm{P}_{\mathrm{fv}, \mathrm{TE}} & =0.879 \\
\mathrm{P}_{\mathrm{fv}, \text { insulator }} & =0.26 \mathrm{e}-13 \\
\mathrm{P}_{\mathrm{fv}, \text { total }} & =0.879\end{aligned}$} \\
\hline & & & Insulator plates & 59.0 & \\
\hline & & & Solder contacts & 29.7 & \\
\hline & \multirow[t]{6}{*}{6} & \multirow[t]{3}{*}{1} & TE legs & 40.1 & \multirow{3}{*}{$\begin{aligned} \mathrm{P}_{\mathrm{fv}, \mathrm{TE}} & =0.204 \\
\mathrm{P}_{\mathrm{fv}, \text { insulator }} & =0.26 \mathrm{e}-14 \\
\mathrm{P}_{\mathrm{fv}, \mathrm{total}} & =0.204\end{aligned}$} \\
\hline & & & Insulator plates & 48.1 & \\
\hline & & & Solder contacts & 26.1 & \\
\hline & & \multirow[t]{3}{*}{2} & TE legs & 55.4 & \multirow{3}{*}{$\begin{aligned} \mathrm{P}_{\mathrm{fv}, \mathrm{TE}} & =0.740 \\
\mathrm{P}_{\mathrm{fv}, \text { insulator }} & =0.17 \mathrm{e}-14 \\
\mathrm{P}_{\mathrm{fv}, \text { total }} & =0.740\end{aligned}$} \\
\hline & & & Insulator plates & 48.8 & \\
\hline & & & Solder contacts & 26.6 & \\
\hline \multirow[t]{12}{*}{$8 \times 8$} & \multirow[t]{6}{*}{3} & \multirow[t]{3}{*}{1} & TE legs & 48.7 & \multirow{3}{*}{$\begin{aligned} \mathrm{P}_{\mathrm{fv}, \mathrm{TE}} & =0.463 \\
\mathrm{P}_{\mathrm{fv}, \text { insulator }} & =0.13 \mathrm{e}-12 \\
\mathrm{P}_{\mathrm{fv}, \text { total }} & =0.463\end{aligned}$} \\
\hline & & & Insulator plates & 66.8 & \\
\hline & & & Solder contacts & 27.0 & \\
\hline & & \multirow[t]{3}{*}{2} & TE legs & 71.6 & \multirow{3}{*}{$\begin{aligned} \mathrm{P}_{\mathrm{fv}, \mathrm{TE}} & =0.999 \\
\mathrm{P}_{\mathrm{fv}, \text { insulator }} & =0.19 \mathrm{e}-12 \\
\mathrm{P}_{\mathrm{fv}, \text { total }} & =0.999\end{aligned}$} \\
\hline & & & Insulator plates & 66.7 & \\
\hline & & & Solder contacts & 28.8 & \\
\hline & \multirow[t]{6}{*}{6} & \multirow[t]{3}{*}{1} & TE legs & 39.1 & \multirow{3}{*}{$\begin{array}{c}\mathrm{P}_{\mathrm{fv}, \mathrm{TE}}=0.298 \\
\mathrm{P}_{\mathrm{fv}, \text { insulator }}=0.810 \mathrm{e}-14 \\
\mathrm{P}_{\mathrm{fv}, \text { total }}=0.298\end{array}$} \\
\hline & & & Insulator plates & 52.9 & \\
\hline & & & Solder contacts & 26.3 & \\
\hline & & \multirow[t]{3}{*}{2} & TE legs & 70.0 & \multirow{3}{*}{$\begin{aligned} \mathrm{P}_{\mathrm{fv}, \mathrm{TE}} & =0.998 \\
\mathrm{P}_{\mathrm{fv}, \text { insulator }} & =0.17 \mathrm{e}-13 \\
\mathrm{P}_{\mathrm{fv}, \text { total }} & =0.998\end{aligned}$} \\
\hline & & & Insulator plates & 56.7 & \\
\hline & & & Solder contacts & 28.4 & \\
\hline \multirow[t]{12}{*}{$10 \times 10$} & \multirow[t]{6}{*}{3} & \multirow[t]{3}{*}{1} & TE legs & 50.2 & \multirow{3}{*}{$\begin{aligned} \mathrm{P}_{\mathrm{fv}, \mathrm{TE}} & =0.591 \\
\mathrm{P}_{\mathrm{fv}, \text { insulator }} & =0.26 \mathrm{e}-12 \\
\mathrm{P}_{\mathrm{fv}, \text { total }} & =0.591\end{aligned}$} \\
\hline & & & Insulator plates & 58.0 & \\
\hline & & & Solder contacts & 27.2 & \\
\hline & & \multirow[t]{3}{*}{2} & TE legs & 83.6 & \multirow{3}{*}{$\begin{array}{c}\mathrm{P}_{\mathrm{fv}, \mathrm{TE}}=1.0 \\
\mathrm{P}_{\mathrm{fv}, \text { insulator }}=0.70 \mathrm{e}-12 \\
\mathrm{P}_{\mathrm{fv}, \text { total }}=1.0\end{array}$} \\
\hline & & & Insulator plates & 71.6 & \\
\hline & & & Solder contacts & 28.6 & \\
\hline & 6 & 1 & TE legs & 41.0 & $\mathrm{P}_{\mathrm{fv}, \mathrm{TE}}=0.410$ \\
\hline & & & Insulator plates & 49.9 & $P_{\mathrm{fv}, \text { insulator }}=0.17 \mathrm{e}-13$ \\
\hline & & & Solder contacts & 26.3 & $\mathrm{P}_{\mathrm{fv}, \mathrm{total}}=0.410$ \\
\hline & & 2 & TE legs & 82.9 & $\mathrm{P}_{\mathrm{fv}, \mathrm{TE}}=1.0$ \\
\hline & & & Insulator plates & 63.4 & $\mathrm{P}_{\mathrm{fv}, \text { insulator }}=0.1 \mathrm{e}-12$ \\
\hline & & & Solder contacts & 33.2 & $\mathrm{P}_{\mathrm{fv}, \text { total }}=1.0$ \\
\hline
\end{tabular}

* Fixed center point of cold surface (bottom surface in model). Rest of TE device is free to deform.

\# Cold surface is restrained with rollers (cold surface prevented from deforming in the direction perpendicular to the TE device).

(a) The listed stress in the solder contact material refers to the Von Mises stress. 
Table IV. Lead telluride ( $\mathrm{PbTe}$ ) with $\Delta \mathrm{T}=250^{\circ} \mathrm{C}$, temperature at hot-side surface $=450^{\circ} \mathrm{C}$, and temperature at cold-side surface $=200^{\circ} \mathrm{C}$.

\begin{tabular}{|c|c|c|c|c|c|}
\hline $\begin{array}{l}\text { Array } \\
\text { size }\end{array}$ & $\begin{array}{l}\text { TE leg } \\
\text { height }\end{array}$ & $\begin{array}{l}\text { Boundary } \\
\text { conditions }\end{array}$ & component & Max S1 & Probability of failure \\
\hline \multirow[t]{12}{*}{$6 \times 6$} & \multirow[t]{6}{*}{3} & \multirow[t]{3}{*}{$1^{*}$} & TE legs & 100.4 & \multirow{3}{*}{$\begin{array}{c}\mathrm{P}_{\mathrm{fv}, \mathrm{TE}}=1.0 \\
\mathrm{P}_{\mathrm{fv}, \text { insulator }}=0.49 \mathrm{e}-10 \\
\mathrm{P}_{\mathrm{fv}, \text { total }}=1.0\end{array}$} \\
\hline & & & Insulator plates & 107.1 & \\
\hline & & & Solder contacts & 27.7 & \\
\hline & & \multirow[t]{3}{*}{$2^{\#}$} & TE legs & 150.3 & \multirow{3}{*}{$\begin{array}{c}\mathrm{P}_{\mathrm{fv}, \mathrm{TE}}=1.0 \\
\mathrm{P}_{\mathrm{fv}, \text { insulator }}=0.19 \mathrm{e}-12 \\
\mathrm{P}_{\mathrm{fv}, \text { total }}=1.0\end{array}$} \\
\hline & & & Insulator plates & 67.6 & \\
\hline & & & Solder contacts & 29.5 & \\
\hline & \multirow[t]{6}{*}{6} & \multirow[t]{3}{*}{1} & TE legs & 92.7 & \multirow{3}{*}{$\begin{array}{c}\mathrm{P}_{\mathrm{fv}, \mathrm{TE}}=1.0 \\
\mathrm{P}_{\mathrm{fv}, \text { insulator }}=0.14 \mathrm{e}-10 \\
\mathrm{P}_{\mathrm{fv}, \text { total }}=1.0\end{array}$} \\
\hline & & & Insulator plates & 82.2 & \\
\hline & & & Solder contacts & 28.3 & \\
\hline & & \multirow[t]{3}{*}{2} & TE legs & 150.5 & \multirow{3}{*}{$\begin{array}{c}\mathrm{P}_{\mathrm{fv}, \mathrm{TE}}=1.0 \\
\mathrm{P}_{\mathrm{fv}, \text { insulator }}=0.67 \mathrm{e}-13 \\
\mathrm{P}_{\mathrm{fv}, \text { total }}=1.0\end{array}$} \\
\hline & & & Insulator plates & 62.6 & \\
\hline & & & Solder contacts & 28.3 & \\
\hline \multirow[t]{12}{*}{$8 \times 8$} & \multirow[t]{6}{*}{3} & \multirow[t]{3}{*}{1} & TE legs & 97.1 & \multirow{3}{*}{$\begin{array}{c}\mathrm{P}_{\mathrm{fv}, \mathrm{TE}}=1.0 \\
\mathrm{P}_{\mathrm{fv}, \text { insulator }}=0.26 \mathrm{e}-8 \\
\mathrm{P}_{\mathrm{fv}, \text { total }}=1.0\end{array}$} \\
\hline & & & Insulator plates & 111.5 & \\
\hline & & & Solder contacts & 28.7 & \\
\hline & & \multirow[t]{3}{*}{2} & TE legs & 164.6 & \multirow{3}{*}{$\begin{array}{c}\mathrm{P}_{\mathrm{fv}, \mathrm{TE}}=1.0 \\
\mathrm{P}_{\mathrm{fv}, \text { insulator }}=0.11 \mathrm{e}-10 \\
\mathrm{P}_{\mathrm{fv}, \text { total }}=1.0\end{array}$} \\
\hline & & & Insulator plates & 97.7 & \\
\hline & & & Solder contacts & 25.4 & \\
\hline & \multirow[t]{6}{*}{6} & \multirow[t]{3}{*}{1} & TE legs & 86.0 & \multirow{3}{*}{$\begin{array}{c}\mathrm{P}_{\mathrm{fv}, \mathrm{TE}}=1.0 \\
\mathrm{P}_{\mathrm{fv}, \text { insulator }}=0.79 \mathrm{e}-10 \\
\mathrm{P}_{\mathrm{fv}, \text { total }}=1.0\end{array}$} \\
\hline & & & Insulator plates & 91.7 & \\
\hline & & & Solder contacts & 29.1 & \\
\hline & & \multirow[t]{3}{*}{2} & TE legs & 180.9 & \multirow{3}{*}{$\begin{array}{c}\mathrm{P}_{\mathrm{fv}, \mathrm{TE}}=1.0 \\
\mathrm{P}_{\mathrm{fv}, \text { insulator }}=0.46 \mathrm{e}-11 \\
\mathrm{P}_{\mathrm{fv}, \text { total }}=1.0\end{array}$} \\
\hline & & & Insulator plates & 94.8 & \\
\hline & & & Solder contacts & 28.9 & \\
\hline \multirow[t]{12}{*}{$10 \times 10$} & \multirow[t]{6}{*}{3} & \multirow[t]{3}{*}{1} & TE legs & & \multirow{3}{*}{$\begin{array}{l}\mathrm{P}_{\mathrm{fv}, \mathrm{TE}}=1.0 \\
\mathrm{P}_{\mathrm{fv}, \text { insulator }}= \\
\mathrm{P}_{\mathrm{fv}, \text { total }}=1.0\end{array}$} \\
\hline & & & Insulator plates & & \\
\hline & & & Solder contacts & & \\
\hline & & \multirow[t]{3}{*}{2} & TE legs & & \multirow{3}{*}{$\begin{array}{l}\mathrm{P}_{\mathrm{fv}, \mathrm{TE}}=1.0 \\
\mathrm{P}_{\mathrm{fv}, \text { insulator }}= \\
\mathrm{P}_{\mathrm{fv}, \text { total }}=1.0\end{array}$} \\
\hline & & & Insulator plates & & \\
\hline & & & Solder contacts & & \\
\hline & 6 & 1 & TE legs & & $\mathrm{P}_{\mathrm{fv}, \mathrm{TE}}=1.0$ \\
\hline & & & Insulator plates & & $\mathrm{P}_{\mathrm{fv}, \text { insulator }}=$ \\
\hline & & & Solder contacts & & $\mathrm{P}_{\mathrm{fv}, \mathrm{total}}=1.0$ \\
\hline & & 2 & TE legs & & $\mathrm{P}_{\mathrm{fv}, \mathrm{TE}}=1.0$ \\
\hline & & & Insulator plates & & $\mathrm{P}_{\mathrm{fv}, \text { insulator }}=$ \\
\hline & & & Solder contacts & & $\mathrm{P}_{\mathrm{fv}, \mathrm{total}}=1.0$ \\
\hline
\end{tabular}

* Fixed center point of hot surface (top surface in model). Rest of TE device is free to deform.

\# Hot surface is restrained with rollers (hot surface prevented from deforming in the direction perpendicular to the TE device). 
Table V. Skutterudite with $\Delta \mathrm{T}=250^{\circ} \mathrm{C}$, temperature at hot-side surface $=450^{\circ} \mathrm{C}$, and temperature at cold-side surface $=200^{\circ} \mathrm{C}$.

\begin{tabular}{|c|c|c|c|c|c|}
\hline $\begin{array}{l}\text { Array } \\
\text { size }\end{array}$ & $\begin{array}{l}\text { TE leg } \\
\text { height }\end{array}$ & $\begin{array}{l}\text { Boundary } \\
\text { conditions }\end{array}$ & component & Max S1 & Probability of failure \\
\hline \multirow[t]{12}{*}{$6 \times 6$} & \multirow[t]{6}{*}{3} & \multirow[t]{3}{*}{$1^{*}$} & TE legs & 114.0 & \multirow{3}{*}{$\begin{aligned} \mathrm{P}_{\mathrm{fv}, \mathrm{TE}} & =0.69 \\
\mathrm{P}_{\mathrm{fv}, \text { insulator }} & =0.20 \mathrm{e}-9 \\
\mathrm{P}_{\mathrm{fv}, \text { total }} & =0.69\end{aligned}$} \\
\hline & & & Insulator plates & 101.0 & \\
\hline & & & Solder contacts & 31.1 & \\
\hline & & \multirow[t]{3}{*}{$2^{\#}$} & TE legs & 168.3 & \multirow{3}{*}{$\begin{aligned} \mathrm{P}_{\mathrm{fv}, \mathrm{TE}} & =0.999 \\
\mathrm{P}_{\mathrm{fv}, \text { insulator }} & =0.76 \mathrm{e}-13 \\
\mathrm{P}_{\mathrm{fv}, \text { total }} & =0.999\end{aligned}$} \\
\hline & & & Insulator plates & 66.0 & \\
\hline & & & Solder contacts & 31.5 & \\
\hline & \multirow[t]{6}{*}{6} & \multirow[t]{3}{*}{1} & TE legs & 112.9 & \multirow{3}{*}{$\begin{aligned} \mathrm{P}_{\mathrm{fv}, \mathrm{TE}} & =0.72 \\
\mathrm{P}_{\mathrm{fv}, \text { insulator }} & =0.79 \mathrm{e}-11 \\
\mathrm{P}_{\mathrm{fv}, \text { total }} & =0.72\end{aligned}$} \\
\hline & & & Insulator plates & 84.8 & \\
\hline & & & Solder contacts & 33.9 & \\
\hline & & \multirow[t]{3}{*}{2} & TE legs & 175.5 & \multirow{3}{*}{$\begin{aligned} \mathrm{P}_{\mathrm{fv}, \mathrm{TE}} & =1.0 \\
\mathrm{P}_{\mathrm{fv}, \text { insulator }} & =0.2 \mathrm{e}-13 \\
\mathrm{P}_{\mathrm{fv}, \text { total }} & =1.0\end{aligned}$} \\
\hline & & & Insulator plates & 57.5 & \\
\hline & & & Solder contacts & 32.8 & \\
\hline \multirow[t]{12}{*}{$8 \times 8$} & \multirow[t]{6}{*}{3} & \multirow[t]{3}{*}{1} & TE legs & 115.5 & \multirow{3}{*}{$\begin{aligned} \mathrm{P}_{\mathrm{fv}, \mathrm{TE}} & =0.826 \\
\mathrm{P}_{\mathrm{fv}, \text { insulator }} & =0.22 \mathrm{e}-8 \\
\mathrm{P}_{\mathrm{fv}, \text { total }} & =0.826\end{aligned}$} \\
\hline & & & Insulator plates & 119.3 & \\
\hline & & & Solder contacts & 31.6 & \\
\hline & & \multirow[t]{3}{*}{2} & TE legs & 173.1 & \multirow{3}{*}{$\begin{array}{c}\mathrm{P}_{\mathrm{fv}, \mathrm{TE}}=1.0 \\
\mathrm{P}_{\mathrm{fv}, \text { insulator }}=0.19 \mathrm{e}-11 \\
\mathrm{P}_{\mathrm{fv}, \text { total }}=1.0\end{array}$} \\
\hline & & & Insulator plates & 85.2 & \\
\hline & & & Solder contacts & 29.5 & \\
\hline & \multirow[t]{6}{*}{6} & \multirow[t]{3}{*}{1} & TE legs & 115.4 & \multirow{3}{*}{$\begin{aligned} \mathrm{P}_{\mathrm{fv}, \mathrm{TE}} & =0.840 \\
\mathrm{P}_{\mathrm{fv}, \text { insulator }} & =0.71 \mathrm{e}-10 \\
\mathrm{P}_{\mathrm{fv}, \text { total }} & =0.840\end{aligned}$} \\
\hline & & & Insulator plates & 101.0 & \\
\hline & & & Solder contacts & 32.4 & \\
\hline & & \multirow[t]{3}{*}{2} & TE legs & 203.4 & \multirow{3}{*}{$\begin{array}{c}\mathrm{P}_{\mathrm{fv}, \mathrm{TE}}=1.0 \\
\mathrm{P}_{\mathrm{fv}, \text { insulator }}=0.63 \mathrm{e}-12 \\
\mathrm{P}_{\mathrm{fv}, \text { total }}=1.0\end{array}$} \\
\hline & & & Insulator plates & 82.4 & \\
\hline & & & Solder contacts & 32.5 & \\
\hline \multirow[t]{12}{*}{$10 \times 10$} & \multirow[t]{6}{*}{3} & \multirow[t]{3}{*}{1} & TE legs & 115.6 & \multirow{3}{*}{$\begin{array}{c}\mathrm{P}_{\mathrm{fv}, \mathrm{TE}}=0.919 \\
\mathrm{P}_{\mathrm{fv}, \text {,nsulator }}=0.80 \mathrm{e}-8 \\
\mathrm{P}_{\mathrm{fv}, \text { total }}=0.919\end{array}$} \\
\hline & & & Insulator plates & 122.9 & \\
\hline & & & Solder contacts & 31.8 & \\
\hline & & \multirow[t]{3}{*}{2} & TE legs & 184.5 & \multirow{3}{*}{$\begin{array}{c}\mathrm{P}_{\mathrm{fv}, \mathrm{TE}}=1.0 \\
\mathrm{P}_{\mathrm{fv}, \text { insulator }}=0.14 \mathrm{e}-10 \\
\mathrm{P}_{\mathrm{fv}, \text { total }}=1.0\end{array}$} \\
\hline & & & Insulator plates & 99.2 & \\
\hline & & & Solder contacts & 31.8 & \\
\hline & 6 & 1 & TE legs & 114.5 & $\mathrm{P}_{\mathrm{fv}, \mathrm{TE}}=0.925$ \\
\hline & & & Insulator plates & 101.5 & $\mathrm{P}_{\mathrm{fv}, \text { insulator }}=0.22 \mathrm{e}-9$ \\
\hline & & & Solder contacts & 32.4 & $\mathrm{P}_{\mathrm{fv}, \text { total }}=0.925$ \\
\hline & & 2 & TE legs & 230.0 & $\mathrm{P}_{\mathrm{fv}, \mathrm{TE}}=1.0$ \\
\hline & & & Insulator plates & 91.0 & $\mathrm{P}_{\mathrm{fv} \text {,insulator }}=0.49 \mathrm{e}-11$ \\
\hline & & & Solder contacts & 32.5 & $\mathrm{P}_{\mathrm{fv}, \mathrm{total}}=1.0$ \\
\hline
\end{tabular}

* Fixed center point of hot surface (top surface in model). Rest of TE device is free to deform.

\# Hot surface is restrained with rollers (hot surface prevented from deforming in the direction perpendicular to the TE device). 


\section{SUMMARY}

The probability of failure for various square-arrayed thermoelectric device designs using bismuth telluride, lead telluride, or skutterudite thermoelectric materials were estimated. Only volumeor bulk-based probability of failure analysis was considered. The effects of the choice of the thermoelectric material, the size of the leg array, the height of the thermoelectric legs, and the boundary conditions on the $\mathrm{P}_{\mathrm{f}}$ of thermoelectric devices were investigated. The use of longer legs, using skutterudites, allowing the thermoelectric device to freely deform while under a thermal gradient, and using smaller arrays promoted higher probabilities of survival.

\section{ACKNOWLEDGEMENTS}

Research sponsored by the U.S. Department of Energy, Assistant Secretary for Energy Efficiency and Renewable Energy, Office of Vehicle Technologies, as part of the Propulsion Materials Program, under contract DE-AC05-00OR22725 with UT-Battelle, LLC. The authors thank A. Shyam and H. Wang for their review and helpful comments.

\section{REFERENCES}

[1] W. D. Kingery, "Factors Affecting Thermal Stress Resistance of Ceramic Materials," Journal of the American Ceramic Society, 38:3-15 (1955).

[2] A. A. Wereszczak, T. P. Kirkland, O. M. Jadaan, and H. Wang, "Strength of Bismuth Telluride," in press, Ceramic Engineering and Science Proceedings, (2009).

[3] J. R. Salvador, J. Yang, X. Shi, H. Wang, A. A. Wereszczak, H. Kong, and C. Uher, "Transport and Mechanical Properties of Yb-Filled Skutterudites," in press, Philosophical Magazine, 2009.

[4] J. R. Salvador, J. Yang, X. Shi, H. Wang, and A. A. Wereszczak, "Transport and Mechanical Property Evaluation of $\left(\mathrm{AgSbTe}_{2}\right)_{1-\mathrm{x}}(\mathrm{GeTe})_{\mathrm{x}}(\mathrm{x}=0.80,0.82,0.85,0.87$ and 0.90)," in press, Journal of Solid State Chemistry, 2009. 